\title{
Should Public Discussion of Political Science Research Be Controlled? Why Interest Group Recommendations on the Proper Procedures for Reporting Research Should Be Treated with Skepticism
}

\author{
Jay P. Greene, Manhattan Institute for Policy Research \\ Paul E. Peterson, Harvard University
}

\begin{abstract}
In 1989, distinguished sociologist James Coleman, upon the receipt of an award from the American Sociological Association's Section on Sociology of Education, asked the following question: "How can the discipline . . . so structure itself that it does not erect norms against research that challenges the conventional wisdom? Or more pointedly, how can the discipline structure itself so as not to violate academic freedom, as it has done in the past?" (1989, 77; italics in original). He reminded his listeners of two occasions when he personally encountered threats to the conduct of research on significant public issues. The first took place in 1976 when the head of the ASA attempted to have him censured by the Association for his research on white flight from cities undergoing desegregation. The second occurred in 1981
\end{abstract}

\begin{abstract}
Jay P. Greene is a senior fellow at the Manhattan Institute for Policy Research. He has conducted evaluations of school choice programs in Milwaukee, Cleveland, and San Antonio. He has also investigated the effects of school choice on civic values and integration. He received his Ph.D. from the government department at Harvard University in 1995.
\end{abstract}

Paul E. Peterson is the Henry Lee Shattuck Professor of Government and director of the Program on Education Policy and Governance at Harvard University. He is an author or editor of numerous books and articles on urban politics, federalism and education policy, including Learning from School Choice (Brookings, 1998). when he was harshly attacked upon the release of research findings indicating that students learned more in private than in public schools.

Coleman pointed out that threats to academic freedom are particularly fierce when research challenges the dominant consensus within the academic community. He drew the audience's attention to the "extraordinarily strong propublic school consensus, the consensus that private schools were inegalitarian, and that Catholic schools were both ineffective and inegalitarian. ... It was this . . consensus against which the [research] had to stand" (76-77). Had Coleman been a political scientist, he might also have mentioned that the propublic school consensus was reinforced by the assiduous efforts of well-organized interest groups.

One might think that such threats to academic discussion are a remnant of the agitation of the 1970s. But efforts to pillory, marginalize, and suppress the results of scholarly research are hardly a thing of the past. In an essay titled "They Blinded Me with Political Science: On the Use of Nonpeer-Reviewed Research in Education Policy," published in this journal, Edward Muir, an associate in the research department of the American Federation of Teachers (AFT), objected to the public presentation and discussion of findings from papers that had not appeared in peer-reviewed pub- lications. "[S]ubsequent controversies ... reveal the perils of using nonpeer-reviewed work," he argued $(1999,762)$. "To present to the general public research that has not endured the scrutiny of peer review, ... while all the time calling the work 'political science,' is a challenge to the very nature of our enterprise as a community of scholars and citizens," he intoned. Elsewhere, he invoked the moral imperative that "We as social scientists must find a way to insure that the integrity of our discipline is maintained" (763-64).

In particular, Muir, using a particularly violent verb, objects to being "blinded" by a paper on the Milwaukee school voucher program that we presented at the 1996 Annual Meeting of the American Political Science Association (Greene, Peterson, and $\mathrm{Du}$ 1996). Forty percent of his essay is devoted to a discussion of this paper, despite the fact that it subsequently appeared in two peerreviewed publications (Greene, Peterson, and Du 1998, 1999).

Given Muir's ethically motivated opposition to the release of nonpeer-reviewed findings, it is of interest to note that the AFT, Muir's employer, regularly issues unreviewed research papers bearing on issues of public policy. For example, in 1997, the AFT released an extended research report that criticized the school voucher program in Cleveland (Murphy, Nelson, and Rosenberg 1997). ${ }^{1}$ The report was 
issued without having appeared in a peer-reviewed journal and was mentioned in the Los Angeles Times, Cleveland Plain Dealer, Columbus Dispatch and Education Week. Similarly, in 1998, the

AFT released an unvetted research paper on the Edison Project, a profitmaking firm that is managing both charter schools and public schools under contract with local school boards (see AFT 1998). ${ }^{2}$ Arti-

cles referring to the study appeared in The New York Times, Education

Week, and the Denver Post. Muir himself is a coauthor of still another AFT research report issued without peer review (Murphy et al. 1997).

Muir's rule may be said to be not applicable to research reports issued by interest groups, however. It might be thought appropriate only, for research prepared by political scientists or other social scientists working at universities. But such an application of the rule would give interest groups the opportunity to release research reports without fear of prompt contradiction by scholars not associated with interest groups. Only after a prolonged period of peer review could alternative information be brought to bear on the issue under policy discussion. The net result would be to bias research available to the public in favor of well-established, vested interest groups that can hire their own research staff. ${ }^{3}$

In addition to overlooking AFT's own practices, Muir carefully selected the reports he chose to demonize, apparently in an effort to serve the interests of the group for which he works. Not only did he focus his moral searchlight on research identifying positive consequences of school choice-a policy AFT opposes-Muir also took some pains to disguise the fact that research he cited favorably was also publicly released prior to peer review. For example, he suggested that our paper was the "first" nonpeerreviewed paper on school choice. He then cited a 1999 article written by
University of Wisconsin political scientist John Witte and pointedly noted that this article had received peer review. Muir conspicuously failed to tell his readers that Witte and his colleagues had released six nonreviewed papers on the Milwaukee voucher program between 1991 and $1997 .{ }^{4}$ References to their contents appeared in The New York Times, Los Angeles Times, Milwaukee Journal-Sentinel,

USA Today, Education Week, at least six other indexed newspapers, and in a 1996 column written by former AFT president, Albert Shanker-all before any of the data had appeared in a peer-reviewed publication. Relying upon nonpeer-reviewed research, Witte testified before the Wisconsin state legislature against a bill expanding the Milwaukee voucher program that was subsequently enacted. Given Muir's opposition to the release of nonpeer-reviewed research-quite specifically with respect to the issue of school choice-it is unclear how he could have failed to mention such serious, repeated "transgressions."

Muir could not simply have overlooked Witte's work. Our 1996 paper, the subject of Muir's complaint, responds to Witte's nonpeerreviewed work. Furthermore, Muir and his colleagues at the AFT discussed Witte's work at length in their 1997 report (Murphy et al. 1997).

Nor is it clear-apart from its subject matter-why Muir singles out our APSA paper for extended discussion. ${ }^{5}$ After all, AFT officials have elsewhere affirmed that presentation of a paper at APSA's Annual Meeting itself constitutes peer review. Albert Shanker, replying to an inquiry about whether Witte's work had been peer reviewed, wrote: "Thank you for your letter asking me to document my statement that Professor John Witte's evaluation of the Milwaukee voucher program has been peer reviewed. A partial accounting of the evidence includes the following: paper presented at the American Political Science Association Annual Meeting, Chicago, September, 1992. ..."

Surely, not everyone would agree with the AFT's apparently official position on peer review. Regardless, our paper-the one Muir says most clearly violates his ethical norm-in fact received considerably more peer attention than many APSA convention papers. It was prepared with the helpful advice of three particularly eminent peers, statisticians Frederick Mosteller and Donald Rubin and sociologist Christopher Jencks, whose assistance we acknowledged. We were especially grateful to Rubin, an expert in randomized experiments (the methodology employed in our study), for reading our entire paper with great care. Then, Witte was invited to serve as a discussant on the panel at which our paper was presented, thereby giving the audience an opportunity to hear the full range of opinions on the subject at hand. As it turned out, Witte chose to exercise his prerogative as a discussant with considerable vigor, leaving the audience under no false impression that the scholarly community had arrived at a consensus concerning our findings.

But even if Muir has been highly selective in the essays he has criticized, has he not raised a general point well worth considering? Should not the political science profession attempt to monitor and control the distribution of papers until they have been published in peerreviewed journals or books? To pose the question is, of course, to answer it. The system that Muir wishes to put into place would formalize the informal censorship about which Coleman expressed grave concern in his ASA address quoted at the beginning of this paper.

Putting to one side questions of academic freedom, consider the practical problems Muir's suggestion raises. Muir objected to the fact that our paper was presented at the APSA Annual Meeting in San Francisco. If Muir would ban our paper, he would also, to be consistent, have to ban all papers that had not been subject to review. Should papers 
presented at APSA meetings first survive peer review?

If the prospect of reviewing convention papers is not daunting enough, then consider the transformation that his proposed reform would have on the dissemination of information throughout the profession. Unlike those in the natural sciences, social science publication schedules are slow and ponderous. To reach their audience in a more timely fashion, scholars are attending conventions in ever greater numbers, emailing their papers to ever more colleagues, and posting research results on their web sites. A rule such as Muir proposed, never suitable for the social sciences, would ban what is fast becoming a universal practice.

But perhaps we could simplify the control of public discussion by limiting the ban to just those papers that are of great public interest. Or, more dangerously, to those that are "controversial." Or maybe we could restrict the distribution of research papers to the scholarly community. Of course, no matter what controls were enacted, once entrepreneurial reporters became convinced an embargoed study had sufficient merit, they would circulate the information to interested readers, most likely with an exposé of the suppression that had been occurring.

Quite apart from these practical considerations, Muir's stated fear that premature public access to social science research findings improperly shapes public discussion of policy issues is quite unfounded. The journalists for the elite print media, who provide initial outlets for social science research results, ordinarily ask for rejoinders from those likely to be dubious about the findings. Not surprisingly, the AFT staff, when asked for their views regarding our research, have welcomed the opportunity to respond. There does not seem to be much danger that a partially informed public will be deceived about the degree of scholarly or interest group consensus.

A ban on the public discussion of nonpeer-reviewed research, moreover, would impede scientific advancement. Consider Robert Putnam's essay on social capital, "Bowling Alone." This treasure trove of ideas, insights, and research findings has circulated widely without yet appearing in a peer-reviewed publication. ${ }^{7}$ Admittedly, the essay has generated controversy; so much, in fact, that an issue of American Prospect was largely devoted to questioning one or another aspect of the Putnam thesis (see Schudson 1996; Skocpol 1996; Vallely 1996). Not a single critic, however, has yet been moved to criticize Putnam for not having his material published in a peer-reviewed journal.

Similarly, Michael Lipsky's seminal piece on "Street-Level Bureaucracy" circulated widely in nonreviewed form long before appearing in print (see Lipsky 1969, 1980). Does anyone think it a scandal that most everyone in the relevant academic and policy communities had read the paper before the book was published? The same question applies to Frances Fox Piven's fabulous analyses of the connections between urban disorder and welfare policy, which bore, on their cover sheets, the insistent invitation to quote, cite, and distribute as frequently and widely as possible. Her papers were devoured by avid readers and significantly shaped the welfare debate long before they reached the peer-reviewed light of day. ${ }^{8}$

Finally, peer review does not eliminate controversy. If an important, engaging study appears in the American Political Science Review, it is more likely to generate controversy than resolve it. Even in the natural sciences, peer review has hardly stifled scientific controversy. Consider the intense debate over whether the universe is expanding, contracting, or standing still. Or whether human behavior is affecting global temperature. Or whether the health effects of second-hand smoke are serious. Indeed, it is hard to imagine science without controversy.

Peer review has its place in political science and the social sciences more generally. Although peer review is slow, tedious and may have the undesirable effect of giving priority to the familiar and acceptable rather than the new and controversial, essays carefully critiqued are often improved. In any case, book and journal editors need to have some mechanism for sorting through the thousands of papers, reports, essays, and manuscripts that come their way. Fortunately, any tendency toward stultifying conformity is mitigated by the fact that the numbers and range of journals now available gives researchers many outlets for their work.

Peer review has many benefits, but it should not be exercised in ways that will slow the exchange of ideas or suppress research that offends the sensibilities of the majority-or the interests of the well-organized.

\section{Notes}

1. For another assessment of the Cleveland voucher program, see Greene, Howell, and Peterson (1998).

2. For an assessment of this research report, see Peterson (1998).

3. For example, the AFT critique of the Edison project (AFT 1998) could not have been promptly assessed (see Peterson 1998).

4. Witte and his colleagues issued the following reports prior to peer review: Witte (1991, 1997); Witte, Bailey, and Thorn (1992,
1993); Witte et al. (1994); and Witte, Sterr, and Thorn (1995). The Rouse study Muir cited as contradicting our findings was also said to be peer reviewed. In fact, it was originally issued prior to peer review. For the nonreviewed version of this paper, see Rouse (1996), which was referenced in the Milwaukee Journal-Sentinel and Education Week. These observations should in no way be taken as a criticism of Rouse or Witte. Had they not issued these papers until after they had been accepted for publication in a peer-reviewed journal, their research findings would not have been available at a time when important policy decisions were being made.

5. At one point, Muir abandoned the topic of peer review, his apparent theme, to offer a series of criticisms of our study. He cited Alex Molnar, a critic of school choice, as an authority who has questioned the statistical merits of our study, even though Molnar himself testified under oath that he does not "at- 
test to be an expert in statistics" (Jackson $\mathrm{v}$ Benson 1996, 196). Muir nonetheless treats Molnar as an authority, reproducing Molnar's observation that our "choice of statistical significance test (a 1-tailed test and a .10 standard) affected [our] interpretation of the results" (1999, 762). In fact, we found that the effect of attending a voucher school on the performance on a standardized achievement test for those students who had been in the program for three or four years was 6.8 national percentile ranking points higher in math and 4.9 points higher in reading than the performance of students in the control group, an effect that is substantively important and statistically significant at the .05 level, using the one-tailed test that is appropriate when the expected effect is either null or in one direction. The math result, moreover, is significant at the .05 level whether one uses a one-tailed or two-tailed test. Muir wrote that Rouse's 1998 study contradicts our finding that voucher students had higher reading scores, but failed to acknowledge that Rouse and we both found significant positive effects of vouchers on math performance (see Rouse 1998). In a nonpeer-reviewed paper by Muir and his colleagues at the AFT, it is expressly admitted that "Rouse essentially replicated" our analysis (Murphy et al. 1997).

6. Letter from Albert Shanker to George Mitchell, Milwaukee, Wisconsin, October 4, 1996. A copy of this letter is available from the authors upon request.

7. The essay has been published in a variety of nonpeer-reviewed publications, however. See, for example, Putnam (1997).

8. Piven (1973), which had not received peer review, is referenced in Peterson and Greenstone (1973, 337).

\section{References}

American Federation of Teachers. 1998 "Student Achievement in Edison Schools: Mixed Results in an Ongoing Experiment" <http://www.aft.org/research/ edisonproject/index.htm $>$. Washington, DC: American Federation of Teachers. Accessed: February 23, 2000.

Coleman, James. 1989. "Response to the Sociology of Education Award." Academic Questions 2(Summer): 76-78.

Greene, Jay P., William G. Howell, and Paul E. Peterson. 1998. "Lessons from the Cleveland Scholarship Program." In Learning from School Choice, ed. Paul E. Peterson and Bryan C. Hassel. Washington, DC: Brookings Institution Press.

—, Paul Peterson, and Jingtao Du. 1996. "The Effectiveness of School Choice in Milwaukee: A Secondary Analysis of Data from the Program's Evaluation." Presented at the Annual Meeting of the American Political Science Association, San Francisco.

_- Paul Peterson, and Jingtao Du. 1998. "School Choice in Milwaukee: A Randomized Experiment." In Learning from School Choice, ed. Paul E. Peterson and Bryan C. Hassel. Washington, DC: Brookings Institution Press.

—, Paul Peterson, and Jingtao Du. 1999. "Effectiveness of School Choice: The Milwaukee Experiment." Education and Urban Society 3(January): 190-213.

Greenstone, J. David, and Paul E. Peterson. 1973. Race and Authority in Urban Politics. New York: Russell Sage.

Jackson v. Benton. 1996. Dane County, Wisconsin. County Circuit Court. No. 95-CV1982. Evidentiary Hearing.

Lipsky, Michael. 1969. "Street-Level Bureaucracy." Presented at the Annual Meeting of the American Political Science Association, New York.

—.1980. Street-Level Bureaucracy: Dilemmas of the Individual in Public Services. New York: Russell Sage.

Muir, Edward. 1999. "They Blinded Me with Political Science: On the Use of NonpeerReviewed Research in Education Policy." PS: Political Science and Politics 32(December): 762-64.
Murphy, Dan F., Howard Nelson, and Bella Rosenberg. 1997. "The Cleveland Voucher Program: Who Chooses? Who Gets Chosen? Who Pays?" <http:// www.aft.org/research/reports/clev/ contents.htm>. Washington, DC: American Federation of Teachers. Accessed: February 23, 2000.

- Bella Rosenberg, Howard Nelson, and Ed Muir. 1999. "Milwaukee Voucher Program a Poor Investment, Says AFT" $<$ http://www.aft.org/research/vouchers/mil/ milw972.htm >. Washington, DC: American Federation of Teachers. Accessed: February 23, 2000.

Peterson, Paul E. 1998. "A Guide to Recent Studies of School Effectiveness." Cambridge, MA: Program on Education Policy and Governance, Harvard University. Manuscript.

Piven, Frances Fox. 1973. "The Urban Crisis: Who Got What and Why." In 1984 Revisited: Prospects for American Politics, ed. Robert Paul Wolff. New York: Alfred A. Knopf.

Putnam, Robert. 1997. "Bowling Alone: Democracy in America at Century's End." In Democracy's Victory and Crisis, ed. Alex Hadenius. New York: Cambridge University Press.

Rouse, Cecilia. 1996. "Private School Vouchers and Student Achievement: An Evaluation of the Milwaukee Parental Choice Program" < http://www.irs.princeton.edu/ pubs/pdfs/371.pdf $>$. Princeton: International Relations Section, Department of Economics, Princeton University.

—. 1998a. "Private School Vouchers and Student Achievement: An Evaluation of the Milwaukee Parental Choice Program." The Quarterly Journal of Economics 113(May): 553-602.

- 1998b. "Schools and Student Achievement: More Evidence from the Milwaukee Parental Choice Program." Economic Policy Review 4(March): 61-76.

Schudson, Michael. 1996. "What if Civic Life Didn't Die?" < http://www. americanprospect.com/archives/25/ 25-cnt1.html>. American Prospect 7(March-April): 17-20.

Shanker, Albert. 1996. “An Important Question." The New York Times, September 1. Advertisement.

Skocpol, Theda. 1996. "Unraveling from Above" <http://www.americanprospect. com/archives/25/25-cnt2.html>. American Prospect 7(March-April): 20-25.

Valley, Richard M. 1996. "Couch-Potato Democracy?" <http://www.americanprospect. com/archives/25/25-cnt3.html >. American Prospect 7(March-April): 25-26.

Witte, John F. 1991. "First Year Report: Milwaukee Parental Choice Program." Madison: Robert M. La Follette Institute of Public Affairs, University of Wisconsin. Manuscript.

-. 1997. "Achievement Effects of the Milwaukee Voucher Program." Presented at the annual meeting of the American Economics Association, New Orleans.

—. 1998. "The Milwaukee Voucher Experiment." Educational Evaluation and Policy Analysis 20(4): 229-51.

- Andrea B. Bailey, and Christopher A. Thorn. 1992. "Second Year Report: Milwaukee Parental Choice Program.” Madison: Robert M. La Follette Institute of Public Affairs, University of Wisconsin. Manuscript.

- Andrea B. Bailey, and Christopher A. Thorn. 1993. "Third Year Report: Milwaukee Parental Choice Program." Madison: Robert M. La Follette Institute of Public Affairs, University of Wisconsin. Manuscript.

- Troy D. Sterr, and Christopher A. Thorn. 1995. "Fifth Year Report: Milwaukee Parental Choice Program." Madison: Robert M. La Follette Institute of Public Affairs, University of Wisconsin. Manuscript.

-, Christopher A. Thorn, Kim M. Pritchard, and Michelle Claiborne. 1994. "Fourth Year Report: Milwaukee Parental Choice Program." Madison: Robert M. La Follette Institute of Public Affairs, University of Wisconsin. Manuscript. 